\title{
The Two Blogospheres: Political Blog Use, Participation, and Sophistication during the 2008 U.S. Election Season
}

\author{
Aaron S. Veenstra \\ School of Journalism, Southern Illinois University Carbondale, Carbondale, IL, USA \\ Email: asveenstra@siu.edu
}

Received 19 August 2014; revised 26 September 2014; accepted 7 October 2014

Copyright (C) 2014 by author and Scientific Research Publishing Inc.

This work is licensed under the Creative Commons Attribution International License (CC BY). http://creativecommons.org/licenses/by/4.0/

(c) (i) Open Access

\begin{abstract}
Despite the attention given to political blogs in recent campaigns, scholars have often overlooked something without which they could not thrive: readers. Moreover, literature has considered that readers have generally done so without taking account of significant differences between conservative and liberal blogs. This study uses panel data collected during the 2008 U.S. election to examine how conservative, liberal, and non-blog readers differ. Results show little demographic difference between readers and non-readers. However, blog readers consume political media that is aligned with their blog use. Blog readers participate more in politics than non-readers as a result of their blog use, particularly readers of liberal blogs. Finally, blog readers exhibit greater political sophistication than non-readers, and develop greater political interest as a result of blog reading.
\end{abstract}

\section{Keywords}

Political Communication, Political Blogs, 2008 U.S. Elections, Political Participation, Partisan Media, Political Sophistication

\section{Introduction}

Though seen as part of "new media", the blog is now more than a decade and a half old. Blog content is now frequently featured by prominent newspaper and television news organizations, in addition to blogs maintained by journalists and professional bloggers at those organizations. Blogs saw a tremendous increase in influence in the mid-2000s, as more than a quarter of all Americans consulted blogs for information concerning the 2008 U.S. elections (Smith, 2009), about double the level from 2004 (Pew, 2008). This jump includes unprecedented use of non-news sources to find political information—social networking and online video sites play important roles, 
and a majority says that they "come across" such information while doing other things online. In many ways, this development makes the political blogosphere look something like an accelerated version of political talk radio. While talk radio matured over a period of decades, moving from early-morning and late-night timeslots into primetime and all-talk formats (Katz, 1991), the political blogosphere became an important organizing and fundraising tool after just a few years, and soon thereafter became an important part of elite American political discourse.

Despite this, political blog research has largely overlooked differences in readership across the liberal and conservative blogospheres, the place of blogs in partisan media, and their role in developing political attitudes and behaviors. This study conceptualizes the blogosphere as split into ideological halves that exist in distinct broader networks of partisan media. It additionally looks for ways to reconcile existing approaches to political sophistication and participation with the increasing tendency toward community-driven political action among sophisticates and the politically-interested in a world of increasingly ideological media consumption (Iyengar \& Hahn, 2009) and socio-political interaction (Adamic \& Glance, 2005; Iyengar, Sood, \& Lelkes, 2012).

\section{Literature Review}

\subsection{Political Blogs and Their Readers}

Blogs have been the subject of a fast-moving, fluid body of research since coming to prominence at the beginning of the 21st century. This work tends to understand the universe of blogs through its genres and largely focuses on particular areas, such as entertainment blogs (Scardaville, 2005), health care blogs (Kim \& Chung, 2007), personal blogs (Nardi, Schiano, \& Gumbrecht, 2004), and political blogs (Drezner \& Farrell, 2008; Wallsten, 2005). The myriad topics covered by blogs introduce a complicating factor in comparing them to other news media, and research has shown that blogs, their readers, and their content are not the same across all genres (Su, Wang, \& Mark, 2005). Additionally, blogs’ traffic varies considerably, with a handful of blogs attracting a significant majority of readers and commenters (Duarte, Mattos, Bestavros, Almeida, \& Almeida, 2007).

Some differences between high-traffic and low-traffic blogs are self-evident. High-traffic bloggers have significantly grown in prominence and many now have a seat at the table of elite political discourse. Mainstream political journals such as The Atlantic, National Review, and The American Prospect, and newspapers such as The New York Times and The Washington Post host many of the blogosphere's top names. Those individuals, along with unaffiliated bloggers from top sites such as Hot Air, Firedoglake, and NewsBusters.org are now featured regularly on cable news discussions. This marriage of old and new niche political media blurs the boundaries of what constitutes a "blog" (Garden, 2012) and suggests that the semi-professionalized top end of the political blogosphere is distinct from the bottom end (Veenstra, Brownfield, Howie, Liu, Luo, \& Xie, 2010), though network analyses indicate clear connections between them as well (Adamic \& Glance, 2005; Karpf, 2012). A study by the Institute for Politics, Democracy \& the Internet indicated that $75 \%$ of blog readers read one of the top 11 political blogs at least "once in a while", suggesting that these sites act as hubs for the bulk of readers, regardless of what smaller sites they may also visit (Graf, 2006).

The election season of 2004 prompted the first systematic examinations of blog readers. Eveland and Dylko (2007) examined data from their own survey and from the Pew Internet and American Life Project's election survey, which respectively found $15 \%$ and $9 \%$ of the population having read political blogs. Although some significant demographic differences between readers and non-readers were apparent, demographic characteristics failed to predict blog reading when controlling for online news and discussion habits. A later analysis using data from a survey of Californians similarly found little demographic difference between readers and non-readers (Graf, 2006), except on gender. Blog readers in this sample have higher incomes than non-readers and are more likely to have college degrees, but these differences are minor. Perhaps most notably, the two groups don’t differ at all in age.

Subsequent research conducted during the 2006 mid-term elections suggests that significant new pathways to participation-particularly low-involvement forms, such as contacting an elected official-are fostered by the blogosphere. This is both an active and a passive process, as bloggers appear to have success at motivating their readers to participate (Veenstra, Bode, Wang, Arora, Shah, \& Perlmutter, 2007), and low-efficacy individuals find new ways to participate that don't require the kinds of resources and attitudes necessary for traditional participation (Gil de Zúñiga, Veenstra, Vraga, \& Shah, 2010). This may be a result of blog readers tending toward more extreme issue positions than non-readers (Graf, 2006) — that is, being outside the mainstream of political opinion leads them toward new pathways into the process. While they are active in traditional modes of partici- 
pation, they are also amenable to new options made available by the blogosphere (Gil de Zúñiga, Puig-I-Abril, \& Rojas, 2009).

However, as the tendency to read blogs increases in the general public, rather than moving toward a deliberative online public sphere, a fundamental divide has opened between readers of conservative and liberal blogs. In the early days of the political blogosphere, cross-ideological linking, reading, and discussion were not uncommon (Blood, 2000), in part because the community of political bloggers was extremely small and full of people eager for interaction. As the blogosphere grew, it quickly bifurcated into largely disconnected liberal and conservative halves (Adamic \& Glance, 2005), following the predicted path of ideological homogeneity in the world of multi-channel ideological media (Lawrence, Sides, \& Farrell, 2010), and building on readers' motivation to interact with like-minded others (Kim \& Johnson, 2012). Recent research has shown that the ideological divide in the blogosphere is turning into a significant operational difference between the two blog networks (Karpf, 2012).

Indeed, since roughly 2004 the topology of the blogosphere has undergone significant changes as the medium has mainstreamed and professionalized. Political bloggers are now much more closely aligned with other elites on their side of the political spectrum, and elite bloggers now operate in a much less informal and individual way (Karpf, 2012). Additionally, the largely separate conservative and liberal blogospheres are each dominated by blogs with their own content- and network-related idiosyncrasies. Karpf (2012) notes that, of the top five conservative blogs, three have closed registration (that is, membership is required to either read or comment, and new memberships are not available) and one does not accept comments. This trend is quite the opposite of the open community standard that has filtered down through the liberal blogosphere from Daily Kos and its own forerunners, a standard which lends itself well to activating potential political participants (Andrews, Ganz, Baggetta, Han, \& Lim, 2010). As a result, the gap between conservative and liberal "netroots" increased dramatically in 2008 (Karpf, 2012). This is not to imply that the liberal blogosphere is necessarily dominant or that blogs are inherently more useful to liberal activists. Indeed, relatively greater levels of excitement for Barack Obama compared with John McCain could explain some of the disparity between the two blogospheres in 2008. That difference in enthusiasm points toward two distinct fields of operation, rather than one heterogeneous but cohesive political blogosphere.

All of this suggests that measurements of political blog consumption that don't take content into account, at least at the most basic ideological level, are incomplete and may be misleading. Since liberal and conservative blogs have such different relationships with their associated movements and such different internal social structures, it stands to reason that they will develop different community norms, approaches to political media, paths to political participation, and so on. It also suggests that the conservative and liberal blog reader communities are made up of different kinds of people. Thus, this investigation begins with a research question addressing the basic make-up of the reader population across the partisan blogospheres:

RQ1. What are the demographic characteristics of liberal and conservative blog readers in terms of age, gender, race, education, and income, and how, if at all, do they differ from non-readers?

Recent research makes clear individuals' political media choices are increasingly influenced by ideology (Iyengar \& Hahn, 2009). This is reflected in the findings of Karpf (2012), that the liberal and conservative blogospheres are distinct entities with largely separate readerships (Lawrence et al., 2010). Graf (2006) and the Veenstra and colleagues (2007) suggest an important relationship between political blog readership and elite and niche news media use in general; thus, the following two hypotheses testing usage patterns of blogs and other political media are proposed:

H1. Among blog readers, reading liberal and conservative blogs are negatively related.

H2. Liberal and conservative blog-reading are embedded in different broader patterns of political media consumption.

Beyond simply consuming more "political junkie" media, there is also evidence of a tendency towards political participation among blog readers. Several studies have found blogs to be important components within activist and campaign networks (Gueorguieva, 2008; Kerbel \& Bloom, 2005), but the tests of the relationship between blog-reading and participation in the general population have provided mixed results (Eveland \& Dylko, 2007; Lawrence et al., 2010). Because of the changes in how individuals use the Internet for political information and action between 2004 and 2008 (Pew, 2008), this study revisits the notion that blog readers tend to participate more than non-readers in politics, and specifically that readers of liberal blogs were more energized to participate than readers of conservative blogs in 2008, based on campaign idiosyncrasies (Boehlert, 2009). 
H3. Political participation a) is positively associated with both conservative and liberal blog-reading, b) increases across the campaign season as a consequence of conservative and liberal blog-reading, and c) is more strongly associated with liberal blog-reading than conservative.

As bloggers and blog readers are often seen as political elites (O’Malley, 2005) and opinion-leaders (Delwiche, 2005; Drezner \& Farrell, 2008), a number of more salient questions arise about their political sophistication. In particular, there is reason to believe that blog readers differ from the general public on a number of concepts frequently associated with political sophistication, including interest in politics, political knowledge, and attitude constraint.

\subsection{Political Sophistication}

Political sophistication is arguably the lynchpin in our understanding of political information-processing and decision-making. However, its use in the literature is often hampered by unclear definitions, imprecise terminology, and opportunistic operationalization. Interest in the concept began in earnest in the early 1960s, following work by Campbell, Converse, Miller, and Stokes (1960), and later Converse himself (1964), following on then-recent research into the development of abstract concepts in the minds of voters (Smith, Bruner, \& White, 1956). Campbell et al. do not use the term "political sophistication" as such, but do describe different types of ideology as being more or less sophisticated in practice (p. 128). They conceptualize sophistication as the ability to think of politics in abstract ideological terms - the most sophisticated individuals are those who describe their feelings about the major parties in terms of abstract "liberal" or "conservative" tendencies, as opposed to those who express political thoughts without reaching the abstract level that ties issues together.

Conspicuously absent from modern conceptions of political sophistication is any specific understanding of or attention to news media, beyond that briefly suggested by Neuman (1986). This is a significant gap, considering the omnipresence of news media in the American political mind. The new political media environment presents a number of questions about the development of political sophistication, and may offer new tools for identifying it. Blogs and other online information sources contain elements of both print and television, allowing for a variety of intramedium interaction (Veenstra, Sayre, Shah, \& McLeod, 2008) and potentially creating a harmonious environment for the development of all the aspects of sophistication examined by Guo and Moy (1998). Additionally, some evidence suggests that political interest in blog readers may vary as a function of the content of the blogs they read (Veenstra, 2007), with blogs that cover a wider array of topics having readerships with higher levels of interest. Blog readers in general may express higher levels of interest in politics than non-readers, and blog reading should be associated with growth in interest during a high-salience period such as a presidential campaign. The same is likely true of political knowledge. Blog readers not only consume an unusually high amount of traditional news content (Hwang, Thorson, Borah, Cleland, \& Perlmutter, 2007), they also are exposed to myriad additional information (Lawson-Borders \& Kirk, 2005; Singer, 2005). Repeated exposure to basic political information is likely to occur while reading blogs, suggesting that blog readers will be better versed in these facts than non-readers.

Finally, the ideologically sorted nature of the blogosphere suggests significant attitude constraint among blog readers. As the two blogospheres become more and more distinct, the political and social norms of the competing ideologies should become more and more dominant within each community (Bagozzi, Dholakia, \& Pearo, 2007; Wellman \& Gulia, 1999), and individual readers' attitudes should derive more and more from broader ideologies. The Tea Party pushback by the conservative movement, including many prominent bloggers (Malkin, 2009), against Republican Party leadership suggests that this may be happening to a greater extent in the conservative blogosphere than in the liberal one.

Thus, the following hypotheses are proposed to test the relationships between blog reading and several indicators of political sophistication:

H4. Both liberal and conservative blog-reading are positively related to a) political interest, b) political attitude constraint, c) political knowledge. Additionally, and d) conservative blog-reading is more strongly related to attitude constraint than is liberal blog-reading.

\section{Methods}

Data for this study were collected as part of the Cooperative Campaign Analysis Project, administered by YouGov/Polimetrix (Jackman \& Vavreck, 2009). YouGov/Polimetrix constructed a sampling frame for CCAP from 
the 2007 American Community Study (ACS), including data on age, race, gender, education, marital status, number of children under 18, family income, employment status, citizenship, state, and metropolitan area. The frame was constructed by stratified sampling from the full 2007 ACS sample with selection within strata by weighted sampling with replacements (using the person weights on the public use file). The target sample was selected by stratifying on age, race, gender, education, and state (with battleground states double sampled) using simple random sampling within strata, excluding all non-registered persons.

The baseline wave of CCAP was fielded on December 17, 2007, and was completed by 43,739 panelists. Subsequent waves were fielded in 2008 on January 24, March 21, September 17, October 22 and November 5. Each wave was in the field for approximately two weeks. Though gathered in an unorthodox manner, the sample used in this study is similar to that gathered for the 2008-09 American National Election Study. Both samples have mean ages in the early 50s, slightly skewed toward higher education, and with household incomes somewhat above the national median as reported by the Census Bureau.

Within the March wave, 1101 respondents were randomly selected to answer a subset of more detailed questions pertaining to media use and online behaviors. These respondents were presented a second such set of questions in the October wave. The cases used in this analysis are drawn from these subsamples in the March and October waves. Although this dataset pertains not to the most recent U.S. presidential election, its measurement of partisan blog consumption makes it a unique source for answers to the questions addressed in this study.

\subsection{Variable Construction}

\subsubsection{Political Blog Readership}

Blog readership was measured with two items asking respondents whether they read conservative and liberal political blogs, measured on a four-point scale from Never (1) to Regularly (4) (liberal: $\mathrm{M}=1.49$, SD = .84; conservative: $\mathrm{M}=1.56, \mathrm{SD}=.90)$. For the purpose of comparing readers to non-readers, these two variables were dichotomized, with those who said "Never" being scored 0 and all other responses being scored 1 (33.6\% read conservative blogs, 30.6\% read liberal blogs, $20.5 \%$ read both).

\subsubsection{Demographics}

Age was measured through respondents' selection of their birth year, which was subtracted from 2008 ( $\mathrm{M}=$ $52.92, \mathrm{SD}=13.78)$. Gender was measured with one item distinguishing male and female ( $47.9 \%$ female). Race was measured with one item asking respondents to place themselves in one category among White, Black, Hispanic, Asian, Native American, Middle Eastern, Mixed, and Other; all non-white categories were collapsed (80.9\% white). Education was measured with one item asking respondents to select from no high school, high school graduate, some college, 2-year college, college graduate, and post-grad (Median $=$ Some college, $\mathrm{SD}=$ 1.00). Family income was measured with one item asking respondents to select one of 14 ranges (Median = $\$ 50,000$ - $\$ 59,999, \mathrm{SD}=3.00)$.

\subsubsection{Ideology and Partisanship}

Political party affiliation was measured with one item ranging from Strong Democrat (1) to Strong Republican (7) $(\mathrm{M}=3.87, \mathrm{SD}=2.26 ; 1.3 \%$ of respondents were third party members). This item was folded at the midpoint (4) to create a measure of strength of partisanship running from 0 to $3(\mathrm{M}=2.04$, SD $=1.00)$. Political ideology was measured with a similar single item running from Very Liberal (1) to Very Conservative (5) (M = 3.25 , $\mathrm{SD}=1.10)$. This item was folded at the mid-point (3) to create a measure of strength of ideology $(\mathrm{M}=.84$, $\mathrm{SD}=.75)$.

\subsubsection{Political Participation}

Political participation was measured in the March wave with four items assessing the frequency of contributing money to a political campaign, attending a political meeting, working for a political party, and displaying a campaign button in the last month, from Not at All (1) to Very Frequently (7). These four items were averaged to create an index (Cronbach's $\alpha=.79, \mathrm{M}=1.59, \mathrm{SD}=1.10$ ). Each of these items was measured again in the October wave $(\alpha=.73, \mathrm{M}=1.90, \mathrm{SD}=1.31)$.

Online political activity was measured in the March wave with four items assessing the frequency of reading comments posted on news sites, watching political videos online, forwarding a link to a political video or news story, and receiving a link to a political video or news story in the last month, from Not at All (1) to Very Fre- 
quently (7). These four items were averaged to create an index $(\alpha=.84, \mathrm{M}=2.95, \mathrm{SD}=1.78)$. Each of these items was measured again in the October wave $(\alpha=.85, \mathrm{M}=3.60, \mathrm{SD}=1.95)$.

\subsubsection{Political Interest}

One item asked respondents for their level of interest in politics and current events, ranging from Not Much (1) to Very Much (3). This item was measured the same way in both the March $(\mathrm{M}=2.54$, SD = .64) and October $(\mathrm{M}=2.58, \mathrm{SD}=.60)$ waves.

\subsubsection{Attitude Constraint}

Five issue attitudes were used to measure attitude constraint. Items were reverse-coded as necessary so that higher values indicated a more conservative response. Four of the items asked respondents to select one of several statements that most closest represented their views on immigration (measured from 1 to $2 ; \mathrm{M}=1.58$, SD $=.49$ ), health care (measured from 1 to $3 ; \mathrm{M}=2.10, \mathrm{SD}=.86$ ), the war in Iraq (measured from 1 to $4 ; \mathrm{M}=2.79$, $\mathrm{SD}=1.13$ ), and raising taxes on the wealthy (measured from 1 to $4 ; \mathrm{M}=2.13, \mathrm{SD}=1.17$ ). Additionally, regarding the environment, respondents were asked to place themselves on a feeling thermometer where 0 was labeled "The federal government should take actions to slow the effects of climate change" and 100 was labeled "Maintaining jobs and standard of living should be given priority" $(\mathrm{M}=54.11, \mathrm{SD}=32.91)$. These items were asked only in the March wave. Because these issues were measured on different scales they were standardized before being used to create a measure of attitude constraint $(\alpha=.81)$. The standard deviation of each individual's scores on these items was calculated, providing a measure of how far apart the scores were. This variable was then reversed (Jelen, 1990) to provide a positive measure of attitude constraint $(\mathrm{M}=.66, \mathrm{SD}=.32$, min. $=.01$, $\max .=1.49)$.

\subsubsection{Political Knowledge}

Political knowledge was measured in the October wave of the survey only, with 6 items asking respondents to identify whether personal characteristics applied to McCain, Obama, both of them, or neither of them. These items were recoded as 1 for a correct answer and 0 for an incorrect answer or a "don't know" response. An additive scale was created with the resulting scores $(\alpha=.72, \mathrm{M}=5.09, \mathrm{SD}=1.35)$.

\subsubsection{Media Use}

Use of media other than blogs was measured on the same scale, Never (1) to Regularly (4). These questions covered various print, broadcast, and online news and information sources. Exploratory factor analysis was used to identify scales within the battery of media use questions.

All scales were constructed by averaging sets of two to five items. Print news use was measured across national newspapers, local newspapers, and news magazines $(\alpha=.62, \mathrm{M}=2.40, \mathrm{SD}=.79)$. Network television news use was measured across evening network news broadcasts, local affiliate news broadcasts, news magazine programs, and network morning news programs $(\alpha=.76, \mathrm{M}=2.48, \mathrm{SD}=.80)$. Web news use was measured across local newspaper web sites, TV news web sites, and online news aggregators $(\alpha=.62, \mathrm{M}=2.79$, SD $=.80$ ). News analysis use was measured across Sunday morning news programs, CNN viewership, and MSNBC viewership $(\alpha=.74, \mathrm{M}=2.18, \mathrm{SD}=.89)$. Conservative media use was measured across Fox News viewership and conservative talk radio use $(r=.62, \mathrm{M}=2.08, \mathrm{SD}=1.06)$. Progressive media use was measured across NPR use, PBS viewership, progressive talk radio use, online-only news magazine use, and news satire programs ( $\alpha$ $=.76, \mathrm{M}=1.85, \mathrm{SD}=.71)$.

\section{Results}

Among conservative blog readers, three of the five demographic variables significantly differ from non-readers: gender (33\% female; $\mathrm{t}(948)=6.59, p<.001)$, education (Median $=2$ year college, $\mathrm{SD}=1.41 ; \mathrm{t}(948)=-2.85, p$ $<.01$ ), and income (Median $=\$ 70,000-\$ 79,999, \mathrm{SD}=3.33$; $\mathrm{t}(860)=-3.92, p<.001)$. No significant difference was found for age $(\mathrm{M}=52.70, \mathrm{SD}=13.03$; $\mathrm{t}(948)=.56$, n.s. $)$ or race $(82.1 \%$ white; $\mathrm{t}(948)=-.59$, n.s.). Among liberal blog readers, two demographic variables significantly differ from non-readers: gender (38\% female; $\mathrm{t}(943)=3.80, p<.001$ ) and education (Median $=2$ year college, $\mathrm{SD}=1.41 ; \mathrm{t}(943)=-3.86, p<.001)$. No significant difference was found for income (Median $=\$ 60,000-\$ 69,999, \mathrm{SD}=3.53 ; \mathrm{t}(857)=-.47$, n.s.), age $(\mathrm{M}$ 
$=52.01, \mathrm{SD}=13.08 ; \mathrm{t}(943)=1.62$, n.s. $)$, or race $(79.0 \%$ white; $\mathrm{t}(943)=.98$, n.s. $)$.

Hypothesis $\mathrm{H} 1$ proposes that, among those who ever read blogs, liberal and conservative blog reading are negatively correlated. This hypothesis is proposed conditionally because of the significant majority of respondents who don't read blogs at all (56.2\%). That is, their responses to the liberal and conservative blog items are equal, "Never", which may strongly bias the resulting correlation. Among the full sample, this is reflected in a strong positive relationship $(\mathrm{r}=.36, p<.001)$. However, among those who indicated that they do read either liberal or conservative blogs "Hardly Ever", "Sometimes", or "Regularly", that finding reverses and becomes significantly negative $(\mathrm{r}=-.20, p<.001)$, supporting $\mathrm{H} 1$.

The proposition in $\mathrm{H} 2$, that liberal and conservative blog use are embedded in different patterns of overall news media use, was tested using varimax-rotated factor analysis of a battery of 26 media use measurements. This is the same procedure that was used to generate scales for different types of media use; however, for purposes of this analysis, liberal and conservative blog use were included along with the 24 other media use items. As predicted, the two blog use measures load onto different factors-liberal blog use onto the progressive media factor at .78 and conservative blog use onto the conservative media factor at .69 (full factor loadings can be seen in Table 1).

Table 1. Factor analysis of media consumption behaviors.

\begin{tabular}{|c|c|c|c|c|c|c|}
\hline & \multicolumn{6}{|c|}{ Component } \\
\hline & 1 & 2 & 3 & 4 & 5 & 6 \\
\hline National nightly news & .084 & .753 & -.146 & -.033 & .203 & .146 \\
\hline Local news & -.106 & .782 & .073 & -.007 & -.036 & .102 \\
\hline Sunday morning news shows & .230 & .322 & .195 & .078 & .579 & .124 \\
\hline News magazine shows & .144 & .584 & .023 & -.050 & .320 & .243 \\
\hline Today Show & .000 & .670 & .032 & .033 & .181 & -.020 \\
\hline CNN news programs & .110 & .200 & -.027 & .124 & .778 & .110 \\
\hline Fox news programs & -.286 & -.040 & .757 & .049 & .238 & .089 \\
\hline MSNBC news programs & .307 & .134 & -.076 & .115 & .752 & .082 \\
\hline PBS news and documentary & .518 & .260 & -.077 & .030 & .283 & .193 \\
\hline Late night TV shows & .208 & .567 & -.031 & .152 & .043 & -.112 \\
\hline News satire programming & .522 & .165 & -.238 & .160 & .308 & -.039 \\
\hline National newspapers & .208 & -.015 & .059 & .118 & .178 & .702 \\
\hline National newspaper web sites & .404 & -.128 & -.041 & .522 & .152 & .416 \\
\hline Local newspapers & -.099 & .260 & .042 & -.017 & .004 & .743 \\
\hline Local newspaper web sites & .167 & .222 & .047 & .597 & -.153 & .281 \\
\hline News magazines & .362 & .084 & -.108 & .338 & .170 & .535 \\
\hline News commentary magazines & .471 & -.084 & .227 & .290 & .068 & .456 \\
\hline Online-only news magazines & .712 & -.042 & -.002 & .309 & .094 & .119 \\
\hline Conservative political blogs & .280 & -.121 & .689 & .221 & -.087 & .140 \\
\hline Liberal political blogs & .784 & -.012 & .080 & .201 & .044 & .054 \\
\hline Internet news aggregators & .084 & .010 & .027 & .759 & .081 & -.010 \\
\hline TV news web sites & .056 & .005 & .166 & .702 & .333 & .051 \\
\hline Conservative talk radio & -.056 & -.080 & .842 & .032 & -.035 & .057 \\
\hline Progressive talk radio & .707 & .144 & .144 & -.110 & .113 & -.046 \\
\hline News programming on NPR & .689 & .037 & -.137 & .023 & .128 & .183 \\
\hline Christian programs & .036 & .163 & .559 & -.030 & -.045 & -.109 \\
\hline
\end{tabular}

Note: Extraction Method: Principal Component Analysis. Rotation Method: Varimax with Kaiser Normalization. Rotation converged in 7 iterations. Factor loadings greater than .400 marked in bold. 
Additionally, the blog-enhanced progressive media factor may be more stable than the blog-enhanced conservative media factor. The six progressive items (NPR, PBS, progressive radio, online-only magazines, news satire and liberal blogs) scale with a Cronbach's $\alpha$ of .79 and a mean inter-item correlation of .40, as compared with an $\alpha$ of .76 and mean inter-item correlation of .38 for the original five-item scale. By contrast, the three conservative items (Fox News, conservative radio and conservative blogs) scale with an $\alpha$ of .75 and a mean inter-item correlation of .50, compared to an $\mathrm{r}$ of .62 for the original two items.

Subsequent regression analyses show markedly different relationships between the two blog measures and other media use among blog readers. As in the analysis of $\mathrm{H} 1$, these tests were undertaken only among those who said they read blogs at least "Hardly Ever", to remove the effect of the non-reader majority. Results confirm the differences in news diet between conservative and liberal blog readers. In a regression model using media use to predict conservative blog use, with demographic and political identity variables as controls, conservative media is the only significant media predictor ( $B=.41, p<.001$ ); for liberal blog use, both progressive ( $B$ $=.42, p<.001)$ and conservative media $(\beta=-.15, p<.01)$ are significant (full results in Table 2). Taken together, these results support H2's notion that conservative and liberal blog readers have strongly different diets of elite political media, not just different blog diets.

The contention in hypothesis H3a, that blog readers are more politically participatory than non-readers, was tested with two regression analyses relating traditional and online political activities to both liberal and conservative blog-reading. These models included demographic, political identity, and news media use variables as controls. In the March wave of the survey, partial support was found for H3a, as liberal blog-reading predicted both traditional and online political activities ( $\beta=.19, p<.001 ; \beta=.24, p<.001$, respectively); conservative blog-reading predicted online political activities $(\beta=.16, p<.001$ ), but not traditional political activities ( $ß$ $=.01$, n.s.).

Partial support was also found for H3b's proposition that blog reading predicts an increase in participation duing the campaign. This hypothesis was tested with four regression models predicting traditional and online political activities in October, including March results as a control. Above and beyond that predicted by the March results, liberal blog-reading predicted both traditional $(B=.10, p<.05)$ and online political activity ( $=.16, p<.001)$, while conservative blog-reading predicted change in only online political activity $(\beta=.09, p$ $<.05)$; it did not predict change in traditional participation ( $(=.05$, n.s.). Full results are seen in Table 3.

Table 2. Media use predictors of blog use among blog readers only.

\begin{tabular}{|c|c|c|c|c|}
\hline & \multicolumn{2}{|c|}{ Conservative blogs } & \multicolumn{2}{|c|}{ Liberal blogs } \\
\hline & Model 1 & Model 2 & Model 1 & Model 2 \\
\hline White & -.08 & .00 & -.01 & .02 \\
\hline Age & -.09 & $-.13^{* *}$ & -.06 & -.04 \\
\hline Female & .06 & .05 & -.03 & .04 \\
\hline Education & .00 & .00 & -.02 & -.03 \\
\hline Income & .00 & -.03 & -.01 & -.02 \\
\hline South & -.05 & -.07 & -.04 & -.04 \\
\hline Battleground state & .05 & .03 & -.04 & -.03 \\
\hline Conservative & $.25^{* * * *}$ & $.14^{*}$ & $-.25^{* * *}$ & -.09 \\
\hline Republican & $.36^{* * *}$ & $.23^{* *}$ & $-.39^{* * *}$ & -.13 \\
\hline $\mathrm{R}^{2}$ & $30.1 \%^{* * *}$ & & $36.2 \%{ }^{* * *}$ & \\
\hline Conservative media & & $.41^{* * *}$ & & $-.15^{* *}$ \\
\hline Progressive media & & .07 & & $.42^{* * *}$ \\
\hline Print news & & .08 & & .06 \\
\hline Web news & & .05 & & .08 \\
\hline Network TV news & & .02 & & -.07 \\
\hline TV news analysis & & -.03 & & .06 \\
\hline $\mathrm{R}^{2}$ & & $39.6 \%^{* * *}$ & & $51.0 \%{ }^{* * *}$ \\
\hline
\end{tabular}

Note: Cell entries are standardized betas. ${ }^{* * *} p<.001,{ }^{* *} p<.01,{ }^{*} p<.05$. 
Table 3. Blog use predictors of participation and change in participation.

\begin{tabular}{|c|c|c|c|c|}
\hline & \multicolumn{2}{|c|}{ Traditional participation } & \multicolumn{2}{|c|}{ Online participation } \\
\hline & Cross-section & Change & Cross-section & Change \\
\hline White & -.06 & -.01 & .04 & -.01 \\
\hline Age & $.10^{* *}$ & .02 & .02 & $.08^{*}$ \\
\hline Female & $.10^{* *}$ & -.01 & -.05 & .05 \\
\hline Education & .04 & .03 & .03 & .02 \\
\hline Income & .06 & $.12^{* * * *}$ & .06 & $.10^{* *}$ \\
\hline South & -.02 & -.02 & .00 & -.02 \\
\hline Battleground state & .03 & $.06^{*}$ & -.02 & -.01 \\
\hline Conservative & .09 & -.03 & $.09^{*}$ & -.02 \\
\hline Ideological strength & $.08^{*}$ & .03 & .07 & .01 \\
\hline Republican & -.02 & .00 & -.04 & .02 \\
\hline Partisan strength & .05 & $.07^{*}$ & -.01 & .06 \\
\hline Conservative media & .00 & .03 & -.03 & .03 \\
\hline Progressive media & $.12^{*}$ & .07 & $.09^{*}$ & $.10^{*}$ \\
\hline Print news & .00 & -.07 & $-.08^{*}$ & .03 \\
\hline Web news & .05 & -.03 & $.24^{* * *}$ & .01 \\
\hline Network TV news & $-.09^{*}$ & .01 & -.06 & -.05 \\
\hline TV news analysis & $.12^{* *}$ & .07 & $.14^{* * *}$ & .02 \\
\hline Liberal blogs & $.19^{* * * *}$ & $.10^{*}$ & $.24^{* * *}$ & $.13^{* * *}$ \\
\hline Conservative blogs & .01 & .05 & $.16^{* * *}$ & $.09^{*}$ \\
\hline March participation & & $.46^{* * *}$ & & $.48^{* * *}$ \\
\hline $\mathrm{R}^{2}$ & $14.0 \%^{* * *}$ & $34.1 \%{ }^{* * *}$ & $32.8 \%^{* * *}$ & $44.6 \%^{* * * *}$ \\
\hline
\end{tabular}

Note: Cell entries are standardized betas. ${ }^{* * *} p<.001, \stackrel{* *}{p} p .01,{ }^{*} p<.05$.

Lastly, hypothesis H3c suggested that liberal, rather than conservative, blog-reading has stronger relationships with participation. Partial support was found using Cohen and Cohen's (1975) method to compare effect sizes across all four paired regression models. Liberal blog-reading had a stronger relationship with traditional participation in the March wave $(\mathrm{t}(777)=2.98, p<.01)$, but not with any other model of participation.

Finally, a series of three regression models were used to test hypotheses H4a, H4b, and H4c. Liberal and conservative blog-reading were tested as predictors of political interest, political knowledge, and attitude constraint, with demographic and political identity variables controlled. H4a and H4b, relating blog reading to political interest and knowledge, were supported, while $\mathrm{H} 4 \mathrm{c}$, relating blog reading to attitude constraint, had partial support. Both liberal $(ß=.18, p<.001)$ and conservative blog-reading $(ß=.13, p<.001)$ were significant predictors of political interest. Only liberal blog-reading $(\beta=.23, p<.001)$ predicted political knowledge; conservative blog-reading did not ( $\beta=.03$, n.s.). However, while conservative blog-reading significantly predicted attitude constraint ( $(=.12, p<.01$ ), liberal blog-reading did not ( $\beta=-.01$, n.s.). The test of difference in the betas for attitude constraint shows that they are significantly different $(\mathrm{t}(777)=2.19, p<.05)$; thus, hypothesis $\mathrm{H} 4 \mathrm{~d}$ was supported. Full regression results are seen in Table 4. 
Table 4. Blog use predictors of political sophistication components.

\begin{tabular}{cccc}
\hline & Political interest & Political knowledge & Attitude constraint \\
\hline White & $.10^{* *}$ & .05 & $.08^{*}$ \\
Age & $.12^{* * *}$ & .07 & .03 \\
Female & $-.13^{* * *}$ & -.08 & -.02 \\
Education & $.12^{* * *}$ & $.14^{* *}$ & $.12^{* * *}$ \\
Income & $.09^{*}$ & $.16^{* *}$ & .04 \\
South & .02 & -.01 & .03 \\
Battleground state & .03 & -.04 & .01 \\
Conservative & .05 & .04 & -.06 \\
Ideological strength & .04 & -.03 & $.12^{* * *}$ \\
Republican & .00 & .04 & $.14^{* *}$ \\
Partisan strength & .06 & .08 & $.12^{* * *}$ \\
Liberal blogs & $.18^{* * *}$ & $.23^{* * *}$ & -.01 \\
Conservative blogs & $.13^{* * *}$ & .03 & $.12^{* * *}$ \\
$\mathrm{R}^{2}$ & $17.4 \%^{* * *}$ & $14.6 \% \%^{* * *}$ & $12.0 \%^{* * *}$ \\
\hline
\end{tabular}

Note: Cell entries are standardized betas. ${ }^{* * *} p<.001,{ }^{* *} p<.01,{ }^{*} p<.05$.

\section{Discussion}

The results of these analyses suggest that a re-evaluation of the political blogosphere and its readers may be in order. In demographic terms, political blog readers appear largely similar to non-readers, though they are a bit more educated and strikingly more male. Perhaps most notably, the notion of blog communities as centers of youthful exuberance is not supported by these data, which indicate no significant difference in the ages of blog readers and non-readers. In other words, blog readers look like all other Internet users, for the most part.

However, it appears clear that readers from the liberal and conservative blogospheres are quite different from each other when it comes to their use of blogs and other political media. Though there was little ideological segregation in the early days of political blogs, these results indicate that reading liberal and conservative blogs are negatively related, and that they are embedded in different sets of partisan and niche political media use. While conservative blog use fits with a largely pre-existing set of conservative media sources-Fox News and conservative talk radio-liberal blog use is associated with other forms that have come to prominence contemporaneously with the blogosphere. This suggests a liberal blogosphere that is generally more embedded in the narratives of its movement, and that has greater connections to institutionalized activism. For readers, it suggests more cohesion in the ideas and arguments to which they are exposed, as the liberal movement's media arm has developed as one multi-faceted entity. This could translate into better understanding of the norms of the movement or a stronger appreciation of blogs as a tool for activism.

It may also relate to the finding that liberal blog readers are strong political participators, even compared to the strong tendency to participate among conservative blog readers. That blog readers are stronger participators than non-readers comes as no surprise, considering the explicit requests bloggers make for their readers to participate. Indeed, research has shown that a strong predictor of first-time voting is simply being asked to do so (Adams \& Smith, 1980). Other types of participation may operate in a similar way, whether it comes out of specific requests or a pro-participation norm within the blog community. Fully understanding this process would require extensive content analysis; however, a basic model could use survey questions examining perceptions of blogger habits and blog norms among readers.

The blog readers across the ideological spectrum have higher levels of political interest and knowledge than do non-readers suggests other roles for blog content in future analyses. The greater depth and breadth of blogs, compared with a traditional news diet, should provide more information and more repetition of facts, along with 
more potential starting points for the development of political interest (Veenstra, 2007; Hidi \& Renninger, 2006). The finding that conservative, but not liberal, blog readers have more constrained attitudes than non-readers suggests a role for the internal politics of the conservative and liberal movements in the development of blog communities. The past decade has seen a shaking out in the Republican Party, with moderates leaving and movement conservatives ascending. This is more likely the root cause of the finding than blog reading, per se, as the lack of a similar process on the left seems to bear out. Nonetheless, a more comprehensive approach to attitude constraint—one that specifically examines organizing principles, rather than triangulating them-may find more consistent differences between readers and non-readers. The question will remain difficult to clearly answer because a strongly held but superficial set of attitudes gleaned from partisan media may look like a highly structured ideology in an analytical setting.

Taken as a whole, these findings strongly support the need for political blog usage to be measured separately across liberal and conservative blogs. Although the audience for political blogs is a relatively small part of the overall news audience, much like the audience for cable TV and other niche forms of news content, it is not uniform in what it consumes. Rather, it contains largely distinct sub-groups who read mostly or all liberal blogs or mostly or all conservative blogs, as part of an overall diet of partisan content across media. The data used in this study cannot tell us whether this result carries over to other digital venues, such as social network sites, but do provide a foundation for future exploration in that area. At the least, these results suggest that future study of blogs and other partisan media not be focused solely on the medium, but pay equal attention to the partisan content therein.

While the sample used in this study allows conclusions to be drawn about the American population, it is limited in terms of the concepts that can be operationalized with it. Only $43.8 \%$ of respondents ever read political blogs at all, meaning that any questions that delve further into blog habits, perceptions, or attitudes would be missing values in over half of all cases. This is a significant practical hurdle to any study of blog use that relies on general population survey data. The most appropriate alternative methodology, purposive sampling of blog readers, has its own drawbacks, meaning that the finer details of blogs' place in individuals' political processes may go unstudied until the population of the blogosphere reaches a critical mass. It is for just these reasons that these data are so valuable. Though the Polimetrix model of targeted matching introduces an extra opportunity for error into the data, measures of blog use across political ideology are not available in other sources, nor do other sources provide the opportunity to relate blog use to such a wide variety of political attitudes and behaviors. These data provide a solid first step toward identifying how blogs impact politics at the individual level, which should be replicated and followed-up in future studies.

Additionally, while these conclusions are generalizable in theoretical terms, they should also be understood as a product of the 2008 context. Of course, all election cycles are unique, and relative differences in enthusiasm for Barack Obama and John McCain may help to explain some of these findings. The blogosphere and other new media also remain in a state on continuous flux and development. Between 2004 and 2008, the population of blogosphere became more like the general population, and that trend may have continued into 2012 and beyond. The blogosphere itself has become much bigger (Technorati, 2010) and more ideologically segregated (Karpf, 2012) than it was during the first "blog election" in 2004. So while these findings provide some answers for questions dealing with this period in time, it would be wise to revisit them in during later campaigns, and during non-campaign periods, as assumptions about the new media environment continue to evolve.

\section{References}

Adamic, L., \& Glance, N. (2005). The Political Blogosphere and the 2004 U.S. Election: Divided They Blog: Intelliseek Corporation.

Adams, W. C., \& Smith, D. J. (1980). Effects of Telephone Canvassing on Turnout and Preferences: A Field Experiment. Public Opinion Quarterly, 44, 389-395. http://dx.doi.org/10.1086/268605

Andrews, K., Ganz, M., Baggetta, M., Han, H., \& Lim, C. (2010). Leadership, Membership, and Voice: Civic Associations That Work. American Journal of Sociology, 115, 1191-1242. http://dx.doi.org/10.1086/649060

Bagozzi, R. P., Dholakia, U. M., \& Pearo, L. R. K. (2007). Antecedents and Consequences of Online Social Interactions. Media Psychology, 9, 77-114. http://dx.doi.org/10.1080/15213260709336804

Blood, R. (2000). Weblogs: A History and Perspective. Rebecca’s Pocket.

http://www.rebeccablood.net/essays/weblog_history.html

Boehlert, E. (2009). Bloggers on the Bus: How the Internet Changed Politics and the Press. New York: Free Press. 
Campbell, A., Converse, P. E., Miller, W. E., \& Stokes, D. E. (1960). The American Voter. New York: Wiley.

Cohen, J., \& Cohen, P. (1975). Applied Multiple Regression/Correlation Analysis for the Behavioral Sciences (2nd ed.). Hillsdale, NJ: Lawrence Erlbaum Associates.

Converse, P. E. (1964). The Nature of Belief Systems in Mass Publics. In D. E. Apter (Ed.), Ideology and Discontent (pp. 206-261). New York: The Free Press.

Delwiche, A. (2005). Agenda-Setting, Opinion Leadership, and the World of Web Logs. First Monday, 10. http://dx.doi.org/10.5210/fm.v10i12.1300

Drezner, D., \& Farrell, H. (2008). The Power and Politics of Blogs. Public Choice, 134, 15-30.

Duarte, F., Mattos, B., Bestavros, A., Almeida, V., \& Almeida, J. (2007). Traffic Characteristics and Communication Patterns in Blogosphere. International Conference on Weblogs and Social Media.

Eveland Jr., W. P., \& Dylko, I. (2007). Reading Political Blogs during the 2004 Election Campaign: Correlates and Political Consequences. In M. Tremayne (Ed.), Blogging, Citizenship, and the Future of Media. New York: Routledge.

Garden, M. (2012). Defining Blog: A Fool’s Errand or a Necessary Undertaking. Journalism, 13, 483-499. http://dx.doi.org/10.1177/1464884911421700

Gil de Zúñiga, H. G., Puig-I-Abril, E., \& Rojas, H. (2009). Weblogs, Traditional Sources Online and Political Participation: An Assessment of How the Internet Is Changing the Political Environment. New Media \& Society, 11, 553-574. http://dx.doi.org/10.1177/1461444809102960

de Zúñiga, H. G., Veenstra, A. S., Vraga, E. K., \& Shah, D. V. (2010). Digital Democracy: Reimagining Pathways to Political Participation. Journal of Information Technology \& Politics, 7, 36-51. http://dx.doi.org/10.1080/19331680903316742

Graf, J. (2006). The Audience for Political Blogs. Washington DC: Institute for Politics, Democracy \& the Internet.

Gueorguieva, V. (2008). Voters, MySpace, and YouTube: The Impact of Alternative Communication Channels on the 2006 Election Cycle and Beyond. Social Science Computer Review, 26, 288-300. http://dx.doi.org/10.1177/0894439307305636

Guo, Z., \& Moy, P. (1998). Medium or Message? Predicting Dimensions of Political Sophistication. International Journal of Public Opinion Research, 10, 25-50. http://dx.doi.org/10.1093/ijpor/10.1.25

Hidi, S., \& Renninger, K. A. (2006). The Four-Phase Model of Interest Development. Educational Psychologist, 41, $111-127$. http://dx.doi.org/10.1207/s15326985ep4102_4

Hwang, H., Thorson, K., Borah, P., Cleland, R., \& Perlmutter, D. D. (2007). The Blogosphere and Participatory Democracy: The Role of Hostile Media Perception in Blog Users’ News Source Selection and Expressive Participation. Annual Conference of the Association for Education in Journalism and Mass Communication.

Iyengar, S., \& Hahn, K. S. (2009). Red Media, Blue Media: Evidence of Ideological Selectivity in Media Use. Journal of Communication, 59, 19-39. http://dx.doi.org/10.1111/j.1460-2466.2008.01402.X

Iyengar, S., Sood, G., \& Lelkes, Y. (2012). Affect, Not Ideology: A Social Identity Perspective on Polarization. Public Opinion Quarterly, 76, 405-431. http://dx.doi.org/10.1093/poq/nfs038

Jackman, S., \& Vavreck, L. (2009). The Magic of the Battleground: Learning and Uncertainty in the 2008 Presidential Election. Los Angeles, CA: University of California.

Jelen, T. G. (1990). Religious Belief and Attitude Constraint. Journal for the Scientific Study of Religion, 29, 118-125. http://dx.doi.org/10.2307/1387036

Karpf, D. (2012). The MoveOn Effect: The Unexpected Transformation of American Political Advocacy. New York: Oxford University Press. http://dx.doi.org/10.1093/acprof:oso/9780199898367.001.0001

Katz, J. L. (1991). The Power of Talk. Governing, 4, 38-42.

Kerbel, M. R., \& Bloom, J. D. (2005). Blog for America and Civic Involvement. The International Journal of Press/Politics, 10, 3-27. http://dx.doi.org/10.1177/1081180X05281395

Kim, D., \& Johnson, T. J. (2012). Political Blog Readers: Predictors of Motivations for Accessing Political Blogs. Telematics and Informatics, 29, 99-109. http://dx.doi.org/10.1016/j.tele.2011.04.003

Kim, S., \& Chung, D. S. (2007). Characteristics of Cancer Blog Users. Journal of the Medical Library Association, 95, 445450. http://dx.doi.org/10.3163/1536-5050.95.4.445

Lawrence, E., Sides, J., \& Farrell, H. (2010). Self-Segregation or Deliberation? Blog Readership, Participation, and Polarization in American Politics. Perspectives on Politics, 8, 141-157. http://dx.doi.org/10.1017/S1537592709992714

Lawson-Borders, G., \& Kirk, R. (2005). Blogs in Campaign Communication. American Behavioral Scientist, 49, 548-559. http://dx.doi.org/10.1177/0002764205279425

Malkin, M. (2009). Tea Party USA: The Movement Grows.

http://michellemalkin.com/2009/02/21/tea-party-usa-the-movement-grows/ 
Nardi, B. A., Schiano, D. J., \& Gumbrecht, M. (2004). Blogging as Social Activity, or, Would You Let 900 Million People Read Your Diary? ACM Conference on Computer Supported Cooperative Work.

Neuman, W. R. (1986). The Paradox of Mass Publics: Knowledge and Opinion in the American Electorate. Cambridge, MA: Harvard University Press.

O’Malley, G. (2005). Study: Blog Readers an Elite Minority. Online Media Daily. http://www.mediapost.com/publications/?fa=Articles.showArticle\&art_aid=28115

Pew (2008). Internet’s Broader Role in Campaign 2008: Pew Research Center for the People \& the Press.

Scardaville, M. C. (2005). Accidental Activists: Fan Activism in the Soap Opera Community. American Behavioral Scientist, 48, 881-901. http://dx.doi.org/10.1177/0002764204273174

Singer, J. B. (2005). The Political J-Blogger, “Normalizing” a New Media Form to Fit Old Norms and Practices. Journalism, 6, 173-198. http://dx.doi.org/10.1177/1464884905051009

Smith, A. (2009). The Internet’s Role in Campaign 2008. Washington DC: Pew Internet \& American Life Project.

Smith, M. B., Bruner, J. S., \& White, R. W. (1956). Opinions and Personality. New York: John Wiley and Sons.

Su, N. M., Wang, Y., \& Mark, G. (2005). Politics as Usual in the Blogosphere. 4th International Workshop on Social Intelligence Design.

Technorati (2010). State of the Blogosphere 2010. http://technorati.com/state-of-the-blogosphere-2010/

Veenstra, A. S. (2007). Blogger/Reader Interaction: How Motivations Impact Pathways to Political Interest. Annual Conference of the Midwest Association for Public Opinion Research.

Veenstra, A. S., Bode, L., Wang, M., Arora, M., Shah, D. V., \& Perlmutter, D. D. (2007). Authorship, Intention, and Orientations: How Bloggers and Their Readers Create Participatory Opportunity. Internet Research 8.0., Vancouver.

Veenstra, A. S., Brownfield, K., Howie, A., Liu, X., Luo, J., \& Xie, W. (2010). Serving Two Masters: Intersecting Incentives in the Blogosphere. New Media Theory: How Far Have We Traveled? Lubbock, TX.

Veenstra, A. S., Sayre, B., Shah, D. V., \& McLeod, D. M. (2008). Frames and Knowledge in Mixed Media: How Activation Changes Information Intake. CyberPsychology \& Behavior, 11, 443-450. http://dx.doi.org/10.1089/cpb.2007.0033

Wallsten, K. (2005). Political Blogs and the Bloggers Who Blog Them: Is the Political Blogosphere an Echo Chamber? Annual Conference of the American Political Science Association.

Wellman, B., \& Gulia, M. (1999). Virtual Communities as Communities: Net Surfers Don’t Ride Alone. In M. A. Smith, \& P. Kollock (Eds.), Communities in Cyberspace (pp. 167-194). London: Routledge. 
Scientific Research Publishing (SCIRP) is one of the largest Open Access journal publishers. It is currently publishing more than 200 open access, online, peer-reviewed journals covering a wide range of academic disciplines. SCIRP serves the worldwide academic communities and contributes to the progress and application of science with its publication.

Other selected journals from SCIRP are listed as below. Submit your manuscript to us via either submit@scirp.org or Online Submission Portal.
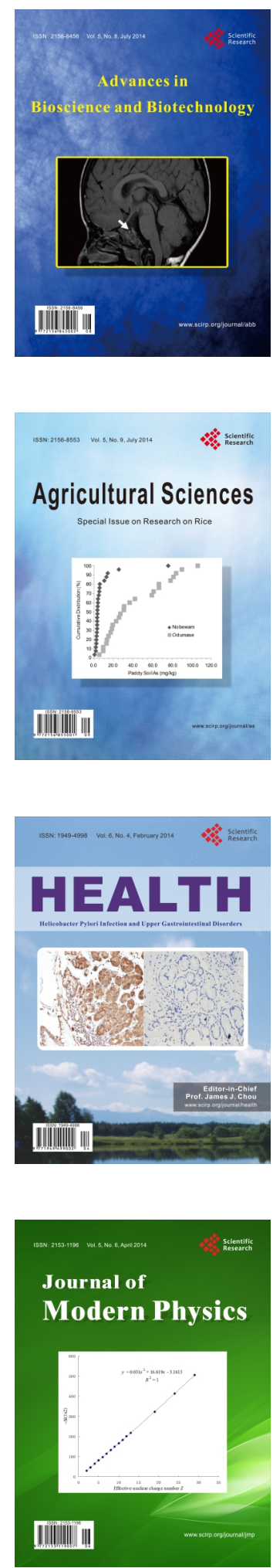
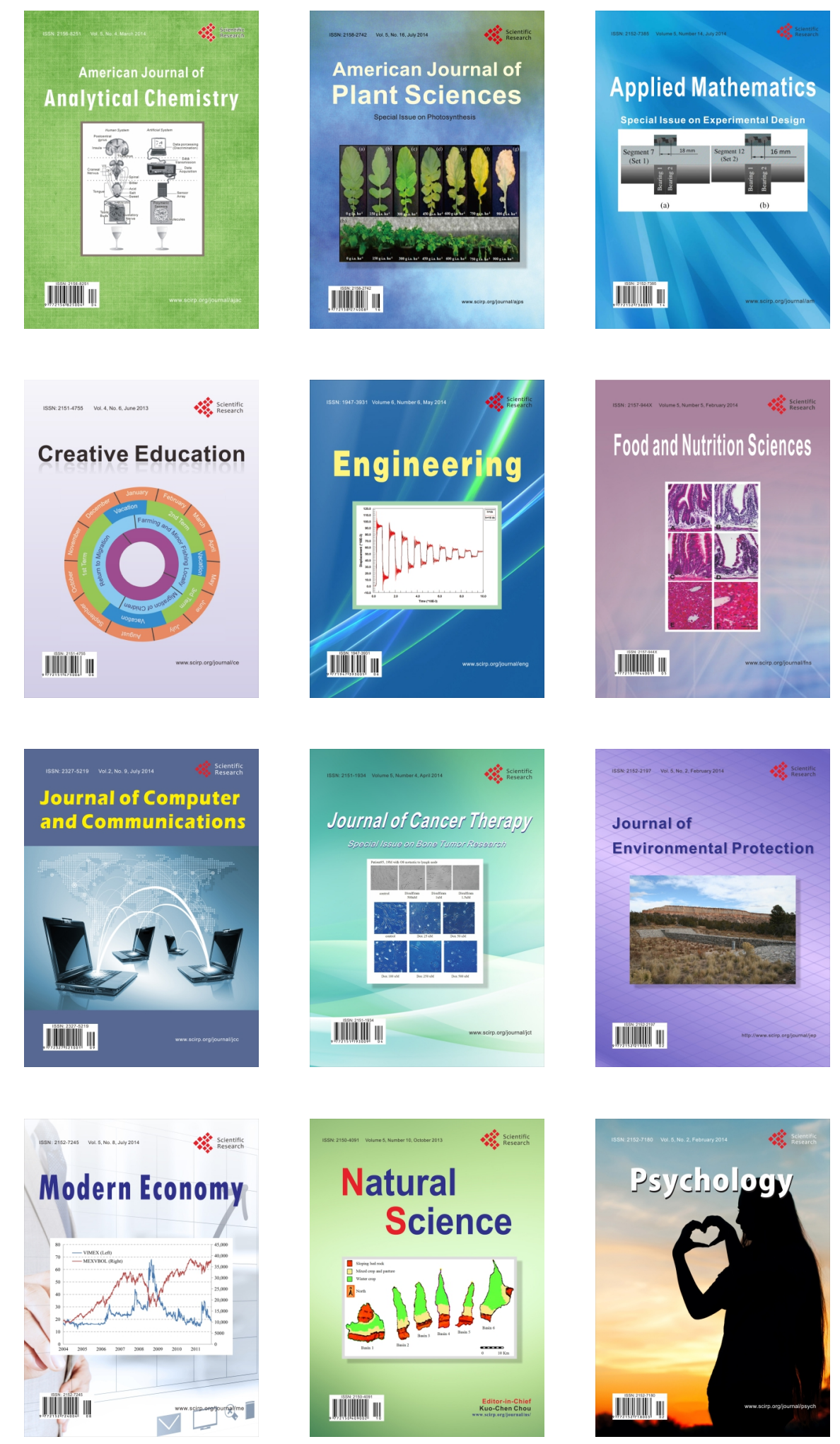